\title{
Fieldwork: An essential component of geoscience education and training
}

\begin{abstract}
Although the importance of fieldwork is ac knowledged in geoscience education and training, fieldwork often is neglected or poorly taught in many countries. One reason for this may be the lack "of expertise on how to teach the subject Another reason may be the reluctance of students-and sometimes teachers - to go to the field Still another reason may be the increasing tendency for geology to be treated as a laboratory science rather than a field science.

The writer believes that (1) teaching field geology should include teaching, at an early stage. geological mapping, evaluation of resources, and all aspects of resource exploitation and utilization: (2) so-called economic geology should become more meaningful, (3) we should revive the seem ingly lost art of making notes and sketches in the field; and (4) more attention should be paid to good scientific writing.
\end{abstract}

\section{Introduction}

Recent articles in some journals have drawn attention to the fact that, although the intportance of fieldwork is acknowledged in geoscience education and training. fieldwork is, in fact, a much neglected component in education, especially in the Third World. The reasons for this contradiction are many, and the object of this article is to look at these reasons, to draw attention once again to the importance of fieldwork, and to suggest ways in which the existing situation can be changed.

One of the main reasons for the neglect of field training in so many parts of the world is the lack of expertise on how to teach ficld geology. It is not enough just to take students on day trips in order 10 show them a few typical outcrops, visit a couple of thines and quarries, and look al some interesting scenic views like escarpments and waterfalls. This type of fieldwork teaches the student something, but it is only a part of what the student needs to know. Hence. the teachers of field geology themselves should know how to teach the subject, and in order to do that, they must know the purpose of the aims and requirements of ficld-geology raining, as diseussed later.

A second reason for neglecting field training may be the absence of a suitable area or areas for teaching field geology in the vicinity of a university. This may be a major obstacle for, in the jargon of modern geological writing, a "constrajn"!). However, very few regions are conpletely devoid of suitable areas for teaching field geology, and it is up to the teacher to find such an area.
Finally, a third reason for neglecting field training may be the reluctance of students - and even teachers! - to do fieldwork. This reluctance must be eliminated from the very beginning. Wo must teach geology students repeatedly that, in spite of many modem developments that are taking place, especially in the laboratotics, geology is still a field science. You cannot be a student of the geosciences without going to the field. In fact. one of the criteria for accepting students in geology should be the student's willingness to go to the field and aptitude for fieldwork.

\section{The neglect of fieldwork}

All this leads me to look at some modern trends in geological research. It bothers me-and a great many others whom I know-that as geology becomes more and more a laboratory science. it also becomes less and less a field science. By this I mean that we increasingly see a tendency to confine working in an area to traversing along roads in moror vebicles, collecting specimens, and working in the laboratories on isotopes, rare-earth elements, microprobes. geothermometry. geobarometry. fluid inclusions, and other highquality but esoteric analyses. This results in solutions to the evolutionary history of such areas that are based almost entirely on such laboratory work. In the course of these sludies, researchers sometimes forget about the basis of all geological studies: the rocks as they occur in the field, their nature, their mineral composition, their structures (mega- and micro-), and their relationships to one another. Rubidium-strontium, samarium-neodymium, and zircon probes may give absolute ages for a set of rocks, but if these ages contradict the field relationships, then to me such ages would be suspect. even wrong! I have no doubt that this may sound like heresy and may call forth a how of protest, but I would defend my viewpoint to the last. Pick up any geological joumal today, and you will see that the majority of the articles deal with such topics as ages, pressuretemperature paths, and "constraints." (As I said above, this word seems to be new jargon that has crept into geological language in recent times and seems to be popular with all modern workers!) Because so few articles deal with actual regional field geology, I am tempted to ask. "Do we not need field geology anymore?"

Let me not be misunderstood. I see very clearly the importance and the need for these laboratory studies. They are essential for a full understanding of the "natural history of crustit rocks," but they are not the whole and ultimate geological studies. In fact. all geoscientific studies, including applied aspects such as tesource geology, bydrogeology, engineering geology, agrogeology, urban geology. and environmental geology, are founded on fieldwork. and this is why l say that training in ficld geology is an essential component of geoscience education and training.

Training in field geology is an aspect that has been neglected in the past 20 or 30 years to the detriment of the geosciences, 1 am bold to say. Furthermore, I say again and again that training in field geology must be brought back into prominence and must be given it rightful place in geoscience education, if we are not to lose sight of 


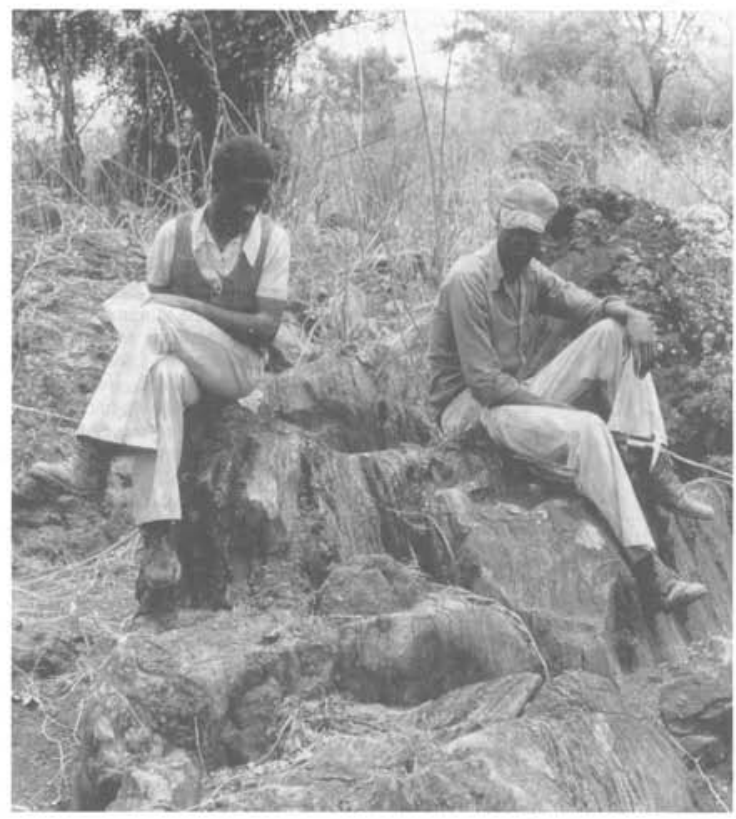

Figure 1.-Two final-year geology students from the University of Zambia doing their independent mapping project.

what geology is all about. I have read that geology students in Romania must do 30 weeks of fieldwork before they can graduate. What a good example to follow!

\section{Teaching field geology}

And so we come to the question, "What are the aims and requirements of teaching field geology?" 1 see two main requirements and two subsidiary ones. The two main requirements are (1) to teach the geology student, at every stage, how to map the geology of an area. however small, and (2) to teach the geology student how to look at resources (rocks, minerals, landforms) in the proper way while taking into account everything that affects or influences their exploitation and utilization.

Teaching the student about geological mapping is of paramount importance during training (fig. 1). Aspiring geologists must be shown how to map in different types of terrain, the methods of mapping (outcrop, traverse, photointerpretation), and mapping at various scales (for example, 1:100,000, 1:50,000, 1:10,000, and larger). They must be shown how to locate themselves on the map or photo when in the field, as well as the procedure to be followed in mapping. They should be taught how to use the landscape, landforms, and soils in order to determine the geology. They should be taught how to use maps and notebooks for recording data, as well as what data to record; how to collect specimens and what to do with the specimens they collect: how to record structural data, what structural data to look for, and what to do with such data. They also should be shown, among other things, how to live under canvas, how to behave in the field, how to respect private property, what safety measures to adopt, and how to avoid destroying interesting exposures by indiscriminate hammering and specimen collection. Because so many things need to be learned in the field, only when one is in the field does one learn what is necessary (fig. 2).

The other major requirement of field geology is teaching the student about resource evaluation. This used to be called "economic geology." but it is more than just looking at a mineral deposit and estimating its reserves. When encountering a known deposit or finding one that was unknown previously, a field geologist should take the trouble to find out all that is possible about the mineral: for example, the known uses of the mineral and its potential uses, the market price and world trade, the methods of mining the deposit, and the infrastructure needed (transportation, communication, water supply, electricity, and harbors). Indeed, the geology student also should know something about economics and something about mining in order to make a proper evaluation of the deposit.

In addition, 1 said above that two subsidiary requirements are necessary for a good field geologist. These are the ability to make 




Figure 2.-A final-year geology student from the University of Zambia on his independent mapping project.

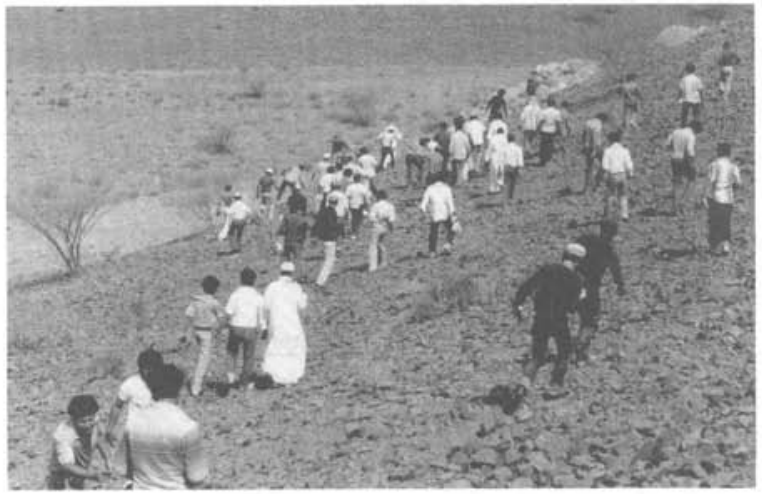

Figure 3.-Geology students from King Abdulaziz University, Jiddah, on the move in Wadi Fatima, Saudi Arabia.

field notes and sketches and the ability to write a good geological or geoscientific report.

\section{Making field notes and sketches}

A basic requirement for effective geological fieldwork is to make good field notes. When mapping outcrops on large-scale maps (for example, $1: 10,000$ ), the mapper will have enough room to make field notes on the map itself. In most developing countries, however, such large-scale maps are not available, and the geologist generally has to work with maps on the scale of 1:63,360 ( 1 inch equals I mile), 1:50,000, or smaller. Because little room is left to make field notes on such maps, it is essential that the field geologist record all data in a field notebook. In order to do this, the geologist must know what to record and how to record it, which he or she can do satisfactorily only if taught how to do it. Unfortunately, such instruction either is poorly given or not given at all, and students generally are left to work out their own systems of taking notes. This should be remedied and can be remedied best in the field itself, where students should be shown the method of taking notes in their very first year of geology studies (fig. 3). 


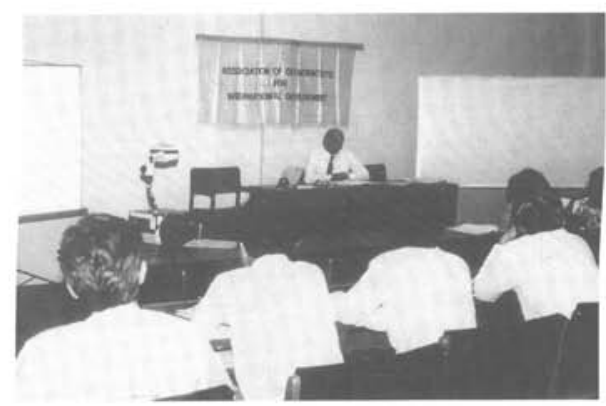

Figure 4.-Geoscientific Writing Workshop, Ipoh, Malaysia.



Figure 5.-Seminar on Scientific and Technical Writing held at Mangalore University, India.

The adjunct to taking notes is making field sketches, and this appears to be a lost art among geologists. This loss is due partly to the advent of the cheap automatic camera and partly to the lack of training in the art of making field sketches. Photographs have their place, but they also have their disadvantages. When you make a sketch in your notebook, the advantages are that (1) you sketch only what is relevant, and you highlight the features in the outcrop or scene; (2) you know exactly where you made the sketch; and (3) you know when you made the sketch.

It is for these reasons that I would like to see the art of making field sketches reintroduced or introduced into the training of geologists. You do not need to be an artist in order to draw a sketch in the field, but you do need a sense of scale and a sense of perspective. These are elementary things that are taught to every schoolboy and schoolgirl at some stage in secondary education in every country. It is up to the teachers of field geology to encourage their students to begin making field sketches in their field notebooks, but of course, in order to do this, the teachers must first be able to do so themselves, And if they are unable to do so, it is time that they taught themselves first in order to teach their students.

\section{The writing of geoscientific reports}

The other subsidiary requirement for effective geological fieldwork is the ability to write reports about the fieldwork that has been done. This is a basic requirement for every geoscientist, whatever his or her discipline. Unfortunately, however, it is also a much neglected area in geoscience education and training. You may be an excellent field geologist, whether in geological mapping, resource investigation, site studies, or other activities, but unless you can present your findings in a readable manner, much of your work may be wasted.

It is important, therefore, that geology students be taught at the undergraduate level how to assemble the data collected, how to structure a geological report, and how to present illustrations, tables, and references (figs, 4 and 5). They also need to be taught the basic rules of good writing, whatever language they write.

\section{Conclusion}

What I have set out to do is to draw attention to the absence of or the poor quality of proper and effective training in field geology in many countries in the world. Note that the term "field geology" includes the making of adequate field notes and sketches and the writing of good geological reports. This is not an easy task, especially in areas where this training has been neglected in the past. We can only hope that those who are able to impart such training will do so, wherever they are.

\section{Acknowledgments}

I thank the President of the International Union of Geological Sciences (IUGS), Professor Umberto Cordani, who knows my thinking and my efforts in this field of geoscience education and training, for suggesting the writing of this article. Dr. David Almond was kind enough to make suggestions for improving the text. $\square$

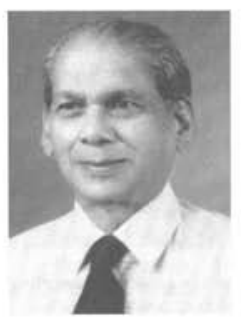

Professor P.G. Cooray has spent the first half of his professional life as a field geologist in the Geological Survey of Sri Lanka and the second half teaching in universities in Nigeria, Zambia, and Saudi Arabia. He also has spent a few years as a Senior Editor in the Directorate General of Mineral Resources in Jiddah, Saudi Arabia. He is now a Senior Research Associate in the Institute of Fundamental Studies in Kandy, Sri Lanka, where he is Coordinator of the Earth and Space Sciences Division and of the Publications Unit. Professor Cooray is a past President of the Association of Geoscientists for Inter. national Development (AGID) and served on the Scientific Committee of the International Geological Correlation Programme (IGCP) from 1980 to 1985. He is currently Chairman of the IUGS Commission on Geoscience Education and Training (COGEOED). 